\title{
GINGIVAL CREVICULAR FLUID OSTEOCALCIN LEVELS IN ELDERLY PATIENT WITH PERIODONTAL DISEASE
}

\author{
YAŞLI BIREYLERDE DiŞETi OLUĞU SIVISI OSTEOKALSIN SEVIYESININ DEĞERLENDIRILMESi
}

Sabri Fatih KURŞUNLU ${ }^{1}$ Veli Özgen ÖZTÜRK ${ }^{1}$ Mehmet Zahit BAŞ ${ }^{2}$

${ }^{1}$ Adnan Menderes University, Dentistry
Faculty, Department Of Periodontology,
Aydın, Turkey
${ }^{2}$ Atatürk University, Dentistry Faculty,
Department Of Maxillo-facial Surgery,
Erzurum, Turkey
Yazışma Adresi:
Yard. Doç. Dr. Sabri Fatih Kurşunlu
Hasan Efendi Mah. No: 1 - Eski Tıp Fakültesi
Yerleşkesi Aydın - Türkiye

E posta: kursunlufatih@hotmail.com

Kabul Tarihi: 22 Ekim 2013

Balıkesir Sağlık Bilimleri Dergisi

ISSN: 2146-9601

e-ISSN: $2147-2238$

bsbd@balikesir.edu.tr

www.bau-sbdergisi.com

\section{ÖZET}

AMAÇ: Kemiğin organik yapısında kollagen olmayan proteinlerden biride osteokalsindir. Osteokalsinin periodontal hastalığın patogenezinde rol oynayan bir markır olabileceği sınırlı sayıda çalışmada gösterilmiştir. Bu çalışmada kronik periodontitsli ve periodontal sağlıklı yaşı bireylerde osteokalsin seviyesinin değerlendirilmesi amaçlanmıştır

YÖNTEMLER: Çalışmaya 10'u kronik periodontitisli, 10'u periodontal sağlıklı 65 yaş üstü toplam 20 birey dahil edilmiştir. Örnek alınan bölgelere ait sondalanan cep derinliği, klinik ataşman seviyesi, papil kanama indeksi ve plak indeksi değerleri kaydedildi. Osteokalsin dişeti oluğu seviyesi ELISA yöntemiyle analiz edildi.

BULGULAR: Kronik periodontitis grubunda dişeti oluğu sıvıSı total miktarı periodontal sağlıklı grubu göre daha az bulunmuştur $(p<0.008)$.

SONUÇ: Çalışma sonuçlarımıza göre osteokalsinin, periodontal hastalıkta anormal kemik yapım-yıkımından sorumlu olabileceğini düşündürmektedir.

Anahtar Kelimeler: Yaşlılık, periodontit, osteokalsin

\section{SUMMARY}

OBJECTIVE: The aim of this cross-sectional study is to investigate gingival crevicular fluid (GCF) osteocalcin levels in chronic periodontitits (CP) and periodontal healthy in elderly subjects. METHODS: 10 patients with CP alone and 10 healthy elderly patients were enrolled. Probing depth, clinical attachment level, plaque index, and papillary bleeding index were recorded. GCF osteocalcin levels were analyzed by enzyme-linked immunosorbent assay. Parametric tests were used for statistical analysis

RESULTS: CP had higher GCF osteocalcin levels compared to healthy groups ( $P<0.05)$. CONCLUSION: The present study might suggest that osteocalcin plays a role on periodontal disease pathogenessis. Fluctuating GCF levels of osteocalcin might point out to the abnormal bone turnover in periodontitis.

Key words: elderly, periodontitis, osteocalcin

\section{INTRODUCTION}

Bone is a specialized connective tissue continuously undergoing remodeling as a result of the coordinated actions of osteoclasts and osteoblasts ${ }^{1}$. Under normal conditions, bone turnover involves a cycle that, at the cellular level, takes place at discrete sites in cancellous and cortical bone ${ }^{2}$. The activity of all of these cellular packages can be measured biochemically by determining markers of bone turnover, which involves bone resorption and formation processes arising from osteoclasts and osteoblasts, respectively. Markers of bone formation are proteins revealing osteoblast activity and are by products of collagen synthesis, matrix proteins or osteoblastic enzymes ${ }^{3,4}$. Osteocalcin is a small
(5.4 kDa), calcium-binding protein of bone accounting for $10-20 \%$ of the non-collagenous protein in bone matrix. It has three residues of a calcium-binding amino acid, gamma-carboxyglutamic acid (Gla), that allow specific conformational changes enabling its binding to hydroxyapatite and later accumulation in bone matrix ${ }^{5,6}$. This vitamin $\mathrm{K}$ - and D-dependent protein produced by mature osteoblasts, osteocytes and odontoblasts, is found in the extracellular mineralized matrix of bone and in the serum of circulating blood ${ }^{5,7}$. It may be involved in regulation of osteoblast function, regulation of bone turnover and/or mineralization. Osteocalcin accepted as a valid marker of bone turnover when resorption and formation are coupled ${ }^{6,8}$. It has been previously shown 
that bone turnover profiles from periodontal bone surfaces and gingival crevicular fluid (GCF) differed from systemic bone turnover profiles ${ }^{9}$. In periodontitis osteocalcin has been suggested to be a marker of bone formation where bone resorption is greater than formation, and GCF osteocalcin levels are more revealing than serum or saliva levels regarding bone turnover in periodontium ${ }^{5}$.To the best of our knowledge, there is no study evaluating the effects of osteocalcin levels on the GCF in elderly patient. We hypothesize that ageing might have an affect on alveolar bone metabolism. The aim of the present study was to examine gingival crevicular fluid osteocalcin levels in periodontal disease.

\section{MATERIALS AND METHODS}

\section{Study population}

A total of 20 subjects were included in this study. All consecutive subjects were recruited from the Department of Periodontology, School of Dentistry, Ege University, Izmir, Turkey. The use of human participants satisfied the requirements of Ege University Institutional Review Board. The purpose of the study was completely explained to each subject before entering the study and informed consent was obtained from each subject in accordance with the Helsinki Declaration of 1975 (revised in 2000). Complete medical and dental histories were taken from all subjects. All of the patients were at least 65 years old, non-smokers, had at least 20 teeth in the mouth. None of the subjects had a history of systemic disease and had received antibiotics or other medications or periodontal treatment within the past 4 months. Patients with severe medical disorders including diabetes mellitus, immunological disorders and pregnant females were excluded from the study. The selection of the patients was made according to the clinical and radiographic criteria ${ }^{10}$. The chronic group included 5 females and 5 males with varying degrees of periodontal disease, also attachment loss were observed. These patients ranged in age from 65 to 81 (mean age $68 \pm 13.6$ years)(Table1). The healthy group consisted of 5 females and 5 males who exhibited PPD $<3 \mathrm{~mm}$ and no clinical attachment loss, clinical inflammation, sulcular bleeding and radiographic evidence of bone loss (mean age $66.7 \pm$ 11.3 years). These individuals were healthy volunteers from the Department of Periodontology. At the screening stage, to determine the clinical periodontal status. Dichotomous measurement of supragingival plaque accumulation and bleeding on probing were also recorded.

\section{Collection of GCF samples}

After being selected for the study, GCF sampling was done from one approximal site of a tooth with bleeding and $\geq 5 \mathrm{~mm}$ probing depth in the chronic group. In the healthy group, GCF samples were collected from one approximal site of a tooth with $\leq 2 \mathrm{~mm}$ probing depth. Prior to GCF sampling, the supragingival plaque was removed from the interproximal surfaces with a sterile curette; these surfaces were dried gently by an air syringe and were isolated by cotton rolls. GCF was sampled with filter paper. Paper strips were carefully inserted into the crevice until mild resistance was felt and left there for 30 seconds $^{11}$. Care was taken to avoid mechanical injury. Strips contaminated with blood were discarded $^{12}$. The absorbed GCF volume of each strip was determined by electronic impedance (Periotron 8000, ProFlow, Inc., Amityville, NY. USA) and placed into a sterile eppendorff vials and kept at $-40^{\circ} \mathrm{C}$ until being analyzed. The readings from the Periotron 8000 were converted to an actual volume $(\mu \mathrm{l})$ by reference to the standard curve.

\section{GCF processing}

The GCF osteocalcin were analyzed by enzyme-linked immunosorbent assay (ELISA) for quantification of this protein in the GCF samples. Manufacturers' guidelines were followed for each assay and 96-well plates precoated with appropriate antibodies were used. The amounts of osteocalcin in each sample were calculated based on the dilutions and the results were expressed as total cytokines in the 30 second GCF sample.

\section{Statistical analysis:}

Statistical analysis was performed using non-parametrical techniques. Comparisons between the study groups were performed using the Mann-Whitney $U$ test. P-values $<0.05$ were considered to be statistically significant. All data analysis was performed using a statistical package.

Table 1. Demographical and site clinical variables between groups.

\begin{tabular}{ccc} 
& $\begin{array}{c}\text { Chronic Periodontitis } \\
\text { Groups }\end{array}$ & Healthy Groups \\
\hline Age & $68 \pm 13.6$ years & $66.7 \pm 11.3$ \\
\hline Gender & $5 \mathrm{~F} / 5 \mathrm{M}$ & $5 \mathrm{~F} / 5 \mathrm{M}$ \\
\hline site(Pocket Depth) & $6.45 \pm 2.33$ & $2.33 \pm 1.03$ \\
\hline $\begin{array}{c}\text { site (Clinical } \\
\text { Atachman Level) }\end{array}$ & $6.77 \pm 2.45$ & $2.35 \pm 1.05$ \\
\hline $\begin{array}{c}\text { site(Papilla Bleeding } \\
\text { Index) }\end{array}$ & $3.00 \pm 0.50$ & $0.30 \pm 0.24$ \\
\hline site(Plaque Index) & $3.75 \pm 0.60$ & $1.06 \pm 0.8$
\end{tabular}




\section{RESULTS}

Chronic periodontitis patients had significantly higher percentage of sites with bleeding on probing and plaque compared to the healthy group $(\mathrm{p}<0.008)$.

Compared to the healthy individuals GCF osteocalcin levels in patients with gingivitis decreased remerkably, (Table 2, p>0.008).

Table 2. Correlations between osteocalcin levels between groups.

\begin{tabular}{lcc}
\hline & $\begin{array}{c}\text { Chronic } \\
\text { Periodontitis }\end{array}$ & Healthy \\
\hline Osteocalcin & $12.83 \pm 3.65^{*}$ & $16.36 \pm 4.84$ \\
\hline $\mathrm{GCF}(\mu \mathrm{l})$ & $0.672^{\ddagger}$ & 0.136 \\
\hline $\mathrm{p}<0.05,{ }^{*} \mathrm{p}<0.008$ & &
\end{tabular}

\section{DISCUSSION}

The analysis of cytokine production levels has been also used as a tool for studying the local host response to a bacterial challenge. Several biomarkers can be detected in the gingival crevicular fluid, which provides a convenient diagnostic fluid to assess the levels of inflammatory mediators released during periodontal disease progression. Increased levels of several proinflammatory cytokines in GCF have been associated with different periodontal disease. However, little is known about the role and presence of the novel or newer cytokines in periodontal diseases and especially in GCF. Therefore, osteocalcin in GCF from patients with different periodontal diseases were analyzed by ELISA in the present study.

On the other hand, there is a controversy about the GCF osteocalcin levels in periodontal diseases. Kunimatsu et all. ${ }^{13}$ did not find osteocalcin in GCF of patients with gingivitis, while in periodontitis GCF osteocalcinwas positively correlatedwith clinical parameters. Lee et al. ${ }^{14}$ demonstrated similar GCF osteocalcin levels in diseased and healthy sites in patients with $\mathrm{CP}$. Wilson et al. ${ }^{15}$ could not detect osteocalcin in GCF of untreated periodontitis patients. On the other hand, Nakashima et al. ${ }^{16}$ found elevated osteocalcin total amount in GCF from periodontitis sites compared to those found in healthy and gingivitis sites. In the present study both periodontitis group compare to the healthy groups. These findings might point out to the abnormal bone turnover in periodontitis. Moreover, variations in osteocalcin levels among different studies as well as the current study might reflect inability to differentiate between sites undergoing attachment loss and others in a "bone loss arrest" state, where clinical signs of PD (CAL, increased PPD, bleeding on probing) are present, but no activity in present.

In the present study we didn't have any 'cause-effect' relationships about osteocalcin. This is also the limitation of our study design. For this purpose, longitudinal studies are necessary to clarify whether osteocalcin influence alveolar bone resorption in periodontal disease.

Identification of novel cytokines as molecular markers which correlated with periodontal disease amend and further extend the understanding of the pathogenesis of periodontal diseases. Additional studies are necessary to clear the role, regulation and function of these cytokines in the pathogenesis of periodontal disease.

\section{REFERENCES}

1. Cochran, D.L. Inflammation and bone loss in periodontal disease. J Periodontol. 2008; 79: 1569-1576.

2. Raska O., Bern'askov'a K, Raska I.JR. Bone metabolism: a note on the significance of mouse models. Physiol Res 2009; . 58: 459-471.

3. Christenson $\mathrm{RH}$. Biochemical markers of bone metabolism: an overview. Clin Biochem. 1997; 30: 573-593.

4. Civitelli R, Armamento-Villareal R, Napoli N, Bone turnover markers: understanding their value in clinical trials and clinical practice. Osteoporos Int. 2009; 20: 843-851.

5. Hauschka, PV, Lian, JB, Cole DE, Gundberg CM. Osteocalcin and matrix Gla protein: Vitamin K-dependent proteins in bone. Physiol Rev. 1989; 69: 990-1047.

6. Lee AJ, Hodges S, Eastell R. Measurement of osteocalcin. Ann Clin Biochem. 2000; 37: 432-446.

7. Hauschka PV. Osteocalcin: the vitamin K-dependent Ca2+binding protein of bone matrix. Haemostasis. 1986;, 16: 258-272.

8. Delmas PD, Eastell R, Garnero P, Seibel MJ, Stepan J. The use of biochemical markers of bone turnover in osteoporosis, Osteoporos Int. 2000; 11(6): 2-17.

9. Wilson AN, Schmid MJ, Marx, DB, Reinhardt RA. , Bone turnover markers in serum and periodontal microenvironments.J Periodont Res. 2003;, 38: 355-361. 
10. Armitage GC. Development of a classification system for periodontal diseases and conditions. Ann Periodontology $1999 ; 4: 1-7$.

11. Lamster IB, Hartley LJ, Oshrain RL. Evaluation and modification of spectrophotometric procedures for analysis of lactate dehydrogenase, beta-glucuronidase and arylsulphatase in human gingival crevicular fluid collected with filter-paper strips. Arch Oral Biol. 1985; 30: 235-242.

12. Cimasoni G. Method of collection. Crevicular fluid updated. 1983 Basel: S.Karger, p.29-36.

13. Kunimatsu K, Mataki STanaka, H, Mine N, Kiyoki M, Hosoda K, Kato Y, Kato I. A cross-sectional study on osteocalcin levels gingingival crevicular fluid from periodontal patients. J Periodontol. 1993; 64: 865-869.

14. Lee AJ,.Walsh TF, Hodges SJ, Rawlinson A. Gingival crevicular fluid osteocalcin in adult periodontitis. J Clin Periodontol. 1999; 26: 252-256.

15. Wilson AN, Schmid MJ, Marx, DB, Reinhardt RA. Bone turnover markers in serum and periodontal microenvironments. J Periodont Res. 2003; 38: 355-361.

16. Nakashima K, Roehrich N, Cimasoni G. Osteocalcin, prostaglandin E2 and alkaline phosphatase in gingival crevicular fluid: Their relations to periodontal status. J Clin Periodontol. 1994;, 21: 327-333. 
